\title{
Morphometry and Ultra-structure of the Intestinal Mucosa of Broilers Fed Different Additives
}

- Author(s)
Pelicano ERL1
Souza PA ${ }^{1}$
Souza HBA ${ }^{1}$
Figueiredo DF
Amaral CMC
1 Departamento de Tecnologia - FCAV/
UNESP. Jaboticabal, SP, Brasil.
2 Departamento de Morfologia e Fisiologia
Animal - FCAV/UNESP. Jaboticabal, SP, Brasil.

Mail Address

Elizabete Regina Leone Pelicano Depto de Tecnologia - FCAV/UNESP

Via de Acesso Prof. Paulo D. Castellane, s/n

Zona Rural

14.870-000. Jaboticabal, SP, Brasil

Phone: 1632037342

E-mail: erlpelicano@yahoo.com.br

\section{Keywords}

Broilers, probiotics, prebiotics, digestive system, intestinal villi.

\section{Acknowledgements}

The authors thank Fundação de Amparo a Pesquisa do Estado de São Paulo (FAPESP) for providing financial resources.

\section{ABSTRACT}

This study aimed at evaluating the effect of the use of different growth promoters on the morphometry and ultra-structure of the intestinal mucosa of 42-day-old broilers. A total number of 36 male Cobb broilers was distributed in a randomized experimental design with a $3 \times 3$ factorial arrangement, with 3 prebiotic and 3 probiotic sources in the feed, summing up 9 treatments, with 4 replicates each. There was a significant interaction $(P<0.01)$ among the studied factor for villi height $(\mathrm{VH})$ in all intestinal segments, and for crypt depth (CD) in the duodenum and the ileum. In the duodenum, higher villi were obtained in the control group, with the combination of $B$. subtilis and prebiotics, and with the single use of MOS+OA. No VH differences were observed between the control group and those fed prebiotics. In the jejunum, the highest villi were obtained with the use of the bacterial pool, followed by the control group, and by the use of $B$. subtilis. Higher villi were also obtained in the control group and in the groups fed MOS, when $B$. subtilis was used in combination with prebiotics, and when the bacterial pool was used individually or in combination with MOS. In the ileum, the highest villi were obtained with the individual use of $B$. subtilis, and when MOS+OA or MOS were individually used or in combination with the bacterial pool. As to duodenal $C D$, deeper crypts were observed in the control group and in those fed $B$. subtilis or MOS+OA. In the ileum, deeper crypts were also found in the control group and those fed $B$. subtilis. Deeper crypts were also found when the bacterial pool was individually used or in combination with MOS+OA, and with the individual use of MOS. It was concluded that the use of growth promoters was beneficial to increase intestinal villi height when Bacillus subtilis was used in combination with prebiotics. The other growth promoters (M OS+OA, M OS, and bacterial pool), can be individually used in most situations. The tested growth promoters did not influence intestinal villi density.

\section{INTRODUCTION}

The present production systems commonly use antibiotics, either in therapeutic doses to prevent and to control diseases, or in subtherapeutic doses, aiming at growth promotion and performance improvement. However, these applications may pose serious risk to human health when improperly used. The presence of antibiotic residues in animal products may cause many disorders in consumers - from allergy reaction to the possibility of resistance development and consequent selection of resistant microorganisms (Witte, 2000; Gomes \& Demoly, 2005). In this sense, many countries, including Brazil, have been researching alternative products to replace the traditional antibiotic growth promoters, such as prebiotics and probiotics. 
Pelicano ERL, Souza PA, Souza HBA, Figueiredo DF, Amaral CMC
Probiotic action can be explained by mechanisms, such as the production of antimicrobial substances and organic acids, protection of villi and absorptive surfaces against toxins produced by pathogenic microorganisms, and immune system stimulation (Vicent, 1959; Dobrogosz et al., 1991; Ewing \& Cole, 1994; Walker \& Duff, 1998; Pelicano et al., 2002). According to Fox (1988), one of the essential requisites for the establishment of microorganisms in a changing environment, such as the gastrointestinal tract, is their ability to attach to the surface of the intestinal epithelium. This suggests that one way to prevent the colonization of this environment by pathogenic bacteria is to saturate epithelial binding sites by beneficial microorganisms, thereby preventing the attachment of pathogens. This mechanism is presently designated as the "competitive exclusion" principle.

On the other hand, prebiotics act by reducing the replication of several intestinal bacteria - pathogenic or not - due to $\mathrm{pH}$ reduction caused by the increase of lactic acid levels in the cecca (Choi et al., 1994). Some bacteria recognize the binding sites of $M O S$ as intestinal mucosa biding sites, therefore reducing intestinal colonization by pathogenic bacteria. Consequently, in addition to a lower incidence of infection, the mucosa is able to fully perform its secretion and nutrient digestion and absorption functions (lji \& Tivey, 1998). Several authors reported positive effects of prebiotics on the intestinal mucosa. Macari \& Maiorka (2000) observed a significant increase in villi height in the three sections of the small intestine of one-week-old broilers with the addition of MOS, and Dionizio (2001) found higher duodenal villi with the use of prebiotics (FOS, lactose, MOS, and sucrose) in 21- and 42-day-old broilers.

Therefore, this study aimed at evaluating the effects of the use of probiotics, prebiotics, and their combination on histological and morphological indexes of the intestinal mucosa of 42-day-old broilers.

\section{MATERIAL AND METHODS}

\section{Location and Experimental Period}

The present study was carried out in the Optical $M$ icroscopy and Scan Electron M icroscopy laboratories of the School of Agrarian and Veterinary Sciences FCAV/UNESP, Jaboticabal, São Paulo, Brazil.

\section{Birds and Management}

The experiment initially used 1260 Cobb male broiler chicks, distributed in 9 treatments with 4 replicates of
Morphometry and Ultra-structure of the Intestinal Mucosa of Broilers Fed Different Additives

35 birds each. Morphometry and ultra-structure analyses were carried out in 36 birds (4 per treatment), with $2.5-\mathrm{kg}$ average live weight at 42 days of age.

Birds were submitted to standard management commonly adopted in commercial broiler production. Birds were housed in a conventional masonry broiler house divided into 36 pens (35 birds/pen) measuring $3.20 \mathrm{~m} \times 1.46 \mathrm{~m}$ (bird density: 8 birds $/ \mathrm{m}^{2}$ ), with $\pm 5-\mathrm{cm}$ thick wood shavings litter, and equipped with chick tube feeders, and aluminum pressure drinkers. During the first rearing weeks, chicks were brooded under infra-red lamps. After the second week of age, $20 \mathrm{~kg}$ capacity tube feeders, and automatic bell drinkers were introduced.

Birds were vaccinated in the hatchery against $M$ arek's disease, and in the broilers house against Infectious Bursal disease and Newcastle disease.

Environmental temperature and air relative humidity were daily recorded, and curtains and fans were managed to ensure bird thermal comfort. Feed and water were offered ad libitum.

\section{Experimental Design and Treatments}

Birds were distributed in a completely randomized experimental design in a $3 \times 3$ factorial arrangement with 3 probiotic dietary sources (no probiotic, probiotic 1 , probiotic 2 ) and 3 prebiotic dietary sources (no prebiotic, prebiotic 1 , prebiotic 2 ), with a total of 9 treatments with 4 replicates of 36 birds each.

The following treatments were applied: 1 - Control (no growth promoter); 2 - Bacillus subtilis; 3 Lacto bacillus acidophilus and casei, Streptococcus lactis and faecium, Bifidobacterium bifidum, and Aspergillus oryzae (bacterial Pool); 4 - phosphorylated mannan oligosaccharide (MOS) and Organic Acidifier (OA); 5 MOS; 6 - Bacillus subtilis + MOS and OA; 7 - Bacillus subtilis + MOS; 8 - Bacterial pool + MOS and OA; 9 Bacterial pool + MOS.

\section{Growth promoter levels in the experimental feeds}

Growth promoter levels were added according to the manufacturors' recommendations:

- Probiotic, based on Bacillus subtilis, was added at $150 \mathrm{~g} /$ ton feed during all rearing phases (01 42 days of age);

- Probiotic, based Lactobacillus acidophilus and casei, Streptococcus lactis and faecium, Bifidobacterium bifidum, and Aspergillus oryzae, was added at $1 \mathrm{~kg} /$ ton feed during all rearing phases (01 - 42 days of age); 
Pelicano ERL, Souza PA, Souza HBA, Figueiredo DF, Amaral CMC
- Prebiotic, based on MOS and AO, was added at $2 \mathrm{~kg} / \mathrm{ton}$ feed in the starter phase (01 - 21 days) and $1.5 \mathrm{~kg} /$ ton thereafter ( 22 - 42 days of age);

- Prebiotic, based on MOS, was added at $1 \mathrm{~kg} /$ ton feed in the starter phase (01 - 21 days) and $0.5 \mathrm{~kg} / \mathrm{ton}$ feed thereafter ( 22 - 42 days of age);

\section{Experimental feeds}

Feeders were filled using dedicated spoons in order to prevent cross-contamination of microorganisms among treatments. The same procedure was adopted with the material used for cleaning the drinkers.

Birds were offered water and feed ad libitum during the entire experimental period, which was divided in three phases. During the starter phase (01-21 days), birds were fed diets containing $3000 \mathrm{kcal} / \mathrm{kg}$ metabolizable energy, $21.4 \%$ crude protein, $1.263 \%$ lysine, $0.561 \%$ methionine, $0.960 \% \mathrm{Ca}$, and $0.450 \%$ available P. Grower diets (22-35 days) contained 3100 $\mathrm{kcal} / \mathrm{kg}$ metabolizable energy, $19.3 \%$ crude protein, $1.156 \%$ lysine, $0.514 \%$ methionine, $0.874 \% \mathrm{Ca}$, and $0.406 \%$ available P. Finisher diets (36-42 days) contained $3200 \mathrm{kcal} / \mathrm{kg}$ metabolizable energy, 18\% crude protein, $1.040 \%$ lysine, $0.445 \%$ methionine, $0.800 \% \mathrm{Ca}$, and $0.365 \%$ available P. Other nutrient levels were added according to the recommendations of Rostagno et al. (2000).

\section{Statistical analysis}

Data were submitted to analysis of variance using Estat 2.0 (1992) software, and means were compared using the test of Tukey at $5 \%$ significance level $(P<0.05)$.

\section{Evaluated parameters}

\section{Morphometry (Optical Microscopy)}

After 12-hour fasting, birds were sacrificed, and duodenum, jejunum, and ileum sections were collected to perform optical microscopy analysis. After collection, these sections were fixed in Bouin's solution for 48 hours. Samples were then dehydrated in graded ethanol concentrations ( $70 \%$ up to absolute), cleared in xylol, embedded in paraffin, cut in microtome at a 5 - $\mu \mathrm{m}$ sections, and stained with Masson's trichrome.

The morphometric study of intestinal villi height and crypt depth (in $\mu \mathrm{m}$ ) was carried out using an imageanalyzing system (Kontron Elektronik - Video Plan), coupled to a binocular microscope (Carl Zeiss). Villi height was measured from the basal region, which corresponded to the higher section of the crypts, to the apex. Crypts were measured from the base up to
Morphometry and Ultra-structure of the Intestinal Mucosa of Broilers Fed Different Additives

the crypt-villus transition region. Fifty villi height and crypt depth readings were performed per treatment/ intestinal section, with a total of 2,700 readings.

\section{Ultra-structure (Scanning Electron Microscopy)}

After 12-hour fasting, birds were sacrificed, and duodenum, jejunum, and ileum sections were collected to perform scanning electron microscopy analysis. These sections were fixed in glutaraldehyde for 24 hours, fixed in phosphate buffer $0.1 \mathrm{M}$, pH 7.4, postfixed in osmium tetroxide at $1 \%$ for 2 hours, washed in the same buffer, and dehydrated in graded ethanol series, from $30 \%, 50 \%, 70 \%, 80 \%, 95 \%$ to $100 \%$ (absolute), where samples where washed three times. Samples were then processed in a critical-point dryer with liquid $\mathrm{CO}_{2}$, in a Bal-Tec apparatus, coated with gold/palladium in a Denton Vacuum Desk II apparatus, and observed under scanning electron microscope (Jeol-Jsm 5410).

In order to measure villi height, samples were electron-microphotographed in three different fields. The scale of each photograph was checked by measuring observation field width and length, thereby resulting in the area of the photograph. Villi were then counted in each field (324 readings/treatment), and the villi number $/ \mu \mathrm{m}^{2}$ was calculated.

\section{RESULTS AND DISCUSSION}

Table 1 presents the analysis of variance relative to villi height (VH), crypt depth (CD), and villi density data. $\mathrm{VH}$ and CD means are summarized in Tables 2 and 3. Table 1 shows that, except for the ileum with the use of prebiotics, probiotics and prebiotics significantly influenced $\mathrm{VH}$ and $\mathrm{CD}$, but there was no effect on villi density. A significant interaction was observed among the studied factor on $\mathrm{VH}$ in all three intestinal segments, whereas CD was affected only in the duodenum and the ileum.

Table 2 presents VH data relative to treatment interactions of in the duodenum, jejunum and ileum of 42-day-old broilers fed different probiotics and prebiotics. In the duodenum, the highest $\mathrm{VH}$ was obtained in the control group, whereas the lowest $\mathrm{VH}$ was observed in the groups fed the in-feed probiotic containing only Bacillus subtilis. However, VH in these two treatments were not different from the group fed with the bacterial pool used as probiotic. Similar results were obtained by Sato (2001), who did not observed any differences in villi morphometry when more than one bacterial culture, consisting of probiotics including 
Pelicano ERL, Souza PA, Souza HBA, Figueiredo DF, Amaral CMC
Morphometry and Ultra-structure of the Intestinal Mucosa of Broilers Fed Different Additives

\begin{tabular}{|c|c|c|c|c|c|c|c|c|c|}
\hline \multirow[b]{2}{*}{ Causes of variation } & \multicolumn{3}{|c|}{ Villi height } & \multicolumn{3}{|c|}{ Crypt depth } & \multicolumn{3}{|c|}{ Villi density } \\
\hline & Duod. & Jejunum & Ileum & Duod. & Jejunum & Ileum & Duod. & Jejunum & Ileum \\
\hline PRO & $5.21 * *$ & $18.54 * *$ & $10.14 * *$ & $16.28 * *$ & $22.78 * *$ & 4.46* & $3.61 \mathrm{~ns}$ & $0.13 n s$ & $0.62 \mathrm{~ns}$ \\
\hline PRE & $14.59 * *$ & $29.35 * *$ & $2.07 n s$ & $13.60 * *$ & $4.89 * *$ & $45.41 * *$ & $0.40 \mathrm{~ns}$ & $0.97 n s$ & $0.04 \mathrm{~ns}$ \\
\hline PRO $\times$ PRE $^{(1)}$ & $5.63^{* *}$ & $20.47 * *$ & $4.13 * *$ & $4.04 * *$ & $0.65 n s$ & $6.60 * *$ & $1.13 \mathrm{~ns}$ & $1.99 \mathrm{~ns}$ & $1.56 \mathrm{~ns}$ \\
\hline CV $(\%)$ & 21.56 & 17.55 & 20.02 & 39.00 & 38.23 & 37.17 & 23.20 & 17.27 & 17.46 \\
\hline
\end{tabular}

${ }^{(1)}$ The details of interactions (PRO $x$ PRE) for villi height and crypt depth are presented in Tables 2 and 3.

Table 2 - Details of PRO x PRE interactions for villi height in the duodenum, jejunum, and ileum of 42-day-old broilers fed in-feed probiotics and prebiotics.

\begin{tabular}{|c|c|c|c|c|}
\hline \multirow[t]{3}{*}{ Treatments } & \multicolumn{3}{|c|}{ Villi height ( $\mu \mathrm{m})$} & \multirow[b]{3}{*}{ Mean } \\
\hline & & In-feed prob & & \\
\hline & No Probiotic & Bacillus subtilis & Pool (1) & \\
\hline In-feed prebiotics & & Duodenum & & \\
\hline No prebiotics & $1740 \mathrm{Aa}^{*}$ & $1400 \mathrm{Bb}$ & $1570 \mathrm{ABa}$ & 1570 \\
\hline MOS+OA & $1786 \mathrm{Aa}$ & $1752 \mathrm{ABa}$ & $1595 \mathrm{Ba}$ & 1711 \\
\hline MOS & $1776 \mathrm{Aa}$ & $1872 \mathrm{Aa}$ & $1738 \mathrm{Aa}$ & 1795 \\
\hline Mean & 1767 & $\begin{array}{l}1675 \\
\text { Jejunum }\end{array}$ & 1634 & \\
\hline No prebiotic & $1529 \mathrm{Ba}$ & $1158 \mathrm{CC}$ & $1702 \mathrm{Aa}$ & 1463 \\
\hline MOS+OA & $1405 \mathrm{Ab}$ & $1338 \mathrm{Ab}$ & $1374 \mathrm{Ab}$ & 1372 \\
\hline MOS & $1558 \mathrm{Aa}$ & $1642 \mathrm{Aa}$ & $1601 \mathrm{Aa}$ & 1600 \\
\hline Mean & 1797 & $\begin{array}{l}1379 \\
\text { Ileum }\end{array}$ & 1559 & \\
\hline No prebiotic & $1225 \mathrm{Aab}$ & $1169 \mathrm{Aa}$ & $1195 \mathrm{Aa}$ & 1196 \\
\hline $\mathrm{MOS}+O \mathrm{~A}$ & $1267 \mathrm{Aa}$ & $1017 \mathrm{Bb}$ & $1163 \mathrm{Aa}$ & 1149 \\
\hline MOS & $1132 \mathrm{ABb}$ & $1100 \mathrm{Bab}$ & $1214 \mathrm{Aa}$ & 1148 \\
\hline Mean & 1208 & 1095 & 1190 & \\
\hline
\end{tabular}

(*) Means followed by the same capital (small letter) in the same row (column) are not different (p>0.05) by the test of Tukey; LSM (Duodenum) $=172$; LSM (Jejunum) = 122; LSM (lleum) = 110. (1) Probiotic based on Lactobacillus acidophilus and casei, Streptococcus lactis and faecium, Bifidobacterium bifidum and Aspergillus oryzae

Tabela 3 - Details of PRO x PRE interactions for crypt depth in the duodenum, and ileum of 42-day-old broilers fed in-feed probiotics and prebiotics.

\begin{tabular}{|c|c|c|c|c|}
\hline \multirow{3}{*}{ Treatments } & \multicolumn{3}{|c|}{ Crypt depth ( $\mu \mathrm{m})$} & \multirow[b]{3}{*}{ Mean } \\
\hline & & Tn-feed probiotics & & \\
\hline & Sem Probiotic & Bacillus subtilis & Pool ${ }^{(1)}$ & \\
\hline In-feed prebiotics & & Duodenum & & \\
\hline No prebiotic & 328 Aa* & $284 \mathrm{Aa}$ & $220 \mathrm{Ba}$ & 277 \\
\hline $\mathrm{MOS}+\mathrm{OA}$ & $325 \mathrm{Aa}$ & $247 \mathrm{Bab}$ & $257 \mathrm{Ba}$ & 276 \\
\hline MOS & $238 \mathrm{Ab}$ & $209 \mathrm{Ab}$ & $225 \mathrm{Aa}$ & 224 \\
\hline Mean & 297 & $\begin{array}{r}246 \\
\text { Ileum }\end{array}$ & 234 & \\
\hline No prebiotic & $281 \mathrm{Aa}$ & $259 \mathrm{Aa}$ & $213 \mathrm{Ba}$ & 251 \\
\hline $\mathrm{MOS}+\mathrm{OA}$ & $182 \mathrm{Ab}$ & $180 \mathrm{Ab}$ & $214 \mathrm{Aa}$ & 192 \\
\hline MOS & $190 \mathrm{Ab}$ & $173 \mathrm{ABb}$ & $147 \mathrm{Bb}$ & 170 \\
\hline Mean & 218 & 204 & 191 & \\
\hline
\end{tabular}

(*) Means followed by the same capital (small letter) in the same row (column) are not different ( $p>0.05$ ) by the test of Tukey; LSM (Duodenum) $=48 ;$ LSM (lleum) = 36. (1) Probiotic based on Lactobacillus acidophilus and casei, Streptococcus lactis and faecium, Bifidobacterium bifidum and Aspergillus oryzae

Bacillus subtilis, Lactobacillus reuteri, and L. johnsonii, was added to the broiler feed, as compared to a control group. The results obtained in the present study indicate that in order to obtain better duodenal morphometry, characterized by higher villi, probiotics containing more than one bacterial culture are required. However, other literature reports show that the use of a single bacterial culture is sufficient to increase $\mathrm{VH}$, such as the results described by
Dobrogosz et al. (1991), who observed a significant increase in intestinal villi height with the use of such products.

No VH differences were observed in the duodenum between the control group and those fed only prebiotics (MOS and OA, or MOS). These results do not agree with those reported by Dionizio (2001), who found an increase in $\mathrm{VH}$ with the use of diets containing MOS as compared to a control group in 42-day-old 
Pelicano ERL, Souza PA, Souza HBA, Figueiredo DF, Amaral CMC broilers. In the present study, higher duodenal VH was observed with the association of Bacillus subtilis with prebiotics, as well as with the individual use of MOS + $\mathrm{OA}$. In the duodenum, it was deduced that the use of probiotics is more beneficial when these are associated with prebiotics, but the same is not true as to prebiotics.

In the jejunum, VH decreased according to the following order: with the individual use of the bacterial pool, followed by diets with no growth promoter inclusion, and finally by diets including only Bacillus subtilis. As observed in the duodenum, the use of probiotics consisting of several bacterial cultures again increased jejunal $\mathrm{VH}$ as compared to probiotics containing a single bacterial culture. According to Andreatti Filho \& Sampaio (2000), a higher number of bacterial species seems to determine higher probiotic efficacy as compared to products with a reduced number of species. Therefore, we can deduce that the higher number of bacterial species contained in the bacterial pool ensure better protection of the villi and of the absorptive surface, having direct influence in the increase of villi height. In addition, according to Cera et al. (1988), maximal absorption and digestion capacity, provided by a large luminal area, with high villi and mature enterocytes, is essential for the animals' development.

Higher VH was also observed in birds fed diets containing only MOS and diets with no growth promoter as compared to those fed diets containing MOS + OA. According to Oyofo et al. (1989 a,b,c), $M O S$ reduces the colonization of the intestine by enteropathogenic bacteria by blocking the binding sites of the intestinal mucosa receptors to bacterial fimbriae. Therefore, the higher VH in the groups fed MOS may result from a lower colonization by pathogenic bacteria, thereby maintaining the integrity of the intestinal mucosa, which then be able to realize its nutrient digestion and absorption functions. Also, in the jejunum, higher VH was observed when Bacillus subtilis was associated with prebiotics, and when the bacterial pool was used individually or associate with MOS. It was again observed that the use of probiotics is more beneficial when it is associated with prebiotics. Balog et al. (2007) observed that the inclusion of a symbiotic (probiotic + prebiotic) in free-range broiler diets significantly improved production performance; however, this product did not change epithelial morphometry (villi height and crypt depth) in all evaluated small intestinal segments.

In the ileum, no VH differences were observed between the groups fed only Bacillus subtilis or the
Morphometry and Ultra-structure of the Intestinal Mucosa of Broilers Fed Different Additives

bacterial pool as compared to the control group. These results are consistent with those obtained and reported by Bradley et al. (1994) and Pelicano et al. (2003), when including probiotics in the feed of broilers from 21 to 35 days, and from 1 to 42 days of age, respectively. In the present study, although not statistically significant, again higher ileum VH was obtained with the use of probiotics containing several bacterial species as compared to the use of individual culture.

As to the individual use of prebiotics, higher ileal VH was observed with the use of MOS associated to $O A$, and lower $\mathrm{VH}$ when MOS was individually used. There was no difference in $\mathrm{VH}$ when the control group was compared with those fed prebiotics. These results disagree with those reported by Loddi (2003) and Corneli et al. (2004), who did not observe differences in $\mathrm{VH}$ among groups fed different dietary prebiotics. However, these studies also showed that both additives did not promote different villi heights as compared to the control group.

In the present study, higher $\mathrm{VH}$ in the ileum was obtained with the individual use of Bacillus subtilis, when MOS + OA were individually used or associated with the bacterial pool, as well as when MOS was used. The ileum was the only intestinal segment that was beneficially affected by the individual used of the probiotic based on Bacillus subtilis.

Table 3 presents $\mathrm{VH}$ data relative to treatment interactions of in the duodenum and ileum of 42-dayold broilers fed different probiotics and prebiotics. Higher CD values were obtained in the duodenum of the birds that did not receive growth promoters and those fed the individual Bacillus subtilis culture, whereas the lowest values were obtained with the use of the bacterial pool. Pelicano et al. (2003) did not find any $C D$ differences between the control group and groups fed probiotics in the feed (Bacillus sp. e Saccharomyces cerevisiae) and in the drinking water (Lactobacillus sp.) when broilers were 42 days of age. On the other hand, Santos et al. (2004), in 21-day-old broilers, observed higher $C D$ values with the use of a bacterial pool (Lactobacillus acidophilus and L. casei, Streptococcus lactis and S. faecium, Bifidobacterium bifidum, and Aspergillus oryzae), and lower CD values in groups that did not receive growth promoters. In the present study, deeper crypts were observed in the control groups and in those fed only MOS +OA, whereas the shallowest crypts were obtained with the individual use of MOS. Similar results were obtained by Loddi (2003), who also found higher $C D$ values in the duodenum of birds fed an association of MOS + OA as compared to the 
Pelicano ERL, Souza PA, Souza HBA, Figueiredo DF, Amaral CMC individual use of MOS. Savage et al. (1996) observed a significant reduction in $C D$ values in the duodenum when MOS was included in a turkey diet; however, Spring (1996) obtained higher CD values in the intestinal mucosa of broilers supplemented with synthetic MOS. In the present experiment, higher CD values were observed in the duodenum with the individual use of Bacillus subtilis, as well as with MOS $+O A$.

Consistent with the results found for the duodenum, deeper crypts were observed in the ileum of birds that did not receive growth promoters, as well in the birds fed the individual Bacillus subtilis culture. Pedroso (1999) also found deeper crypts in the ileum of layers with the continuous dietary inclusion of probiotics based on Bacillus subtilis. In the present study, the highest CD values were observed in the control groups, and the lowest in the groups receiving the individual prebiotics. Similar results, albeit non-significant, were obtained by Loddi (2003), who obtained the highest CD value in the ileum of birds in the control group. We observed higher CD values with the individual use of MOS, Bacillus subtilis, and bacterial pool, and also when the bacterial pool was used in association with MOS and OA.

Table 4 presents data relative to villi density per small intestine segment of broilers fed different probiotics and prebiotics. As evaluated when broilers were 42 days of age, villi density presented the following decreasing order: ileum, jejunum, and duodenum (Figure 1). These results are consistent with those found by Yamauchi \& Ishiki (1991). No differences in villi density were observed among broilers fed probiotics, prebiotics, or those fed the basal diets, in all three evaluated intestinal segments.
Morphometry and Ultra-structure of the Intestinal Mucosa of Broilers Fed Different Additives
Tabela 4 - Villi density (number of villi/1,145,306 $\mu \mathrm{m}^{2}$ ) per small intestine segment of 42 -day-old broilers fed in-feed probiotics and prebiotics.

\begin{tabular}{lccc} 
Treatments & \multicolumn{3}{c}{ Villi density } \\
\cline { 2 - 4 } $\begin{array}{l}\text { In-feed probiotics (PRO) } \\
\text { Duodenum }\end{array}$ & $\begin{array}{l}\text { Jejunum } \\
\text { No Probiotics }\end{array}$ & & lleum \\
Bacillus subtilis & 22 & 32 & 48 \\
Bacterial pool (1) & 27 & 31 & 51 \\
F test & 27 & 30 & 49 \\
LSM (\%) & $3.61 \mathrm{~ns}$ & $0.13 \mathrm{~ns}$ & $0.62 \mathrm{~ns}$ \\
In-feed prebiotics (PRE) & 5.89 & 5.41 & 8.68 \\
No prebiotic & 26 & 32 & \\
M OS+OA & 24 & 29 & 49 \\
M OS & 25 & 32 & 50 \\
F test & $0.40 \mathrm{~ns}$ & $0.97 \mathrm{~ns}$ & $0.04 \mathrm{~ns}$ \\
LSM (\%) & 5.89 & 5.41 & 8.68 \\
\hline PRO x PRE & $1.13 \mathrm{~ns}$ & $1.99 \mathrm{~ns}$ & $1.56 \mathrm{~ns}$ \\
CV (\%) & 23.20 & 17.27 & 17.46 \\
\hline
\end{tabular}

Within the same factor, means followed by the same letter in the same column are not different ( $p>0.05$ ) by the test of Tukey; LSM Least Significant Mean; CV - Coefficient of Variation. (1) Probiotic based on Lactobacillus acidophilus and casei, Streptococcus lactis and faecium, Bifidobacterium bifidum and Aspergillus oryzae.

In the duodenum, villi were more dispersed, in lower numbers, and leaf-shaped, as reported by Yamauchi \& Ishiki (1991) and Sato (2001). In the jejunum, villi presented a zigzag pattern, sometimes suggesting a wave shape, which was also found by Pelicano et al. (2003). According to Yamauchi \& Ishiki (1991), this organization of the villi may promote a more efficient structure for nutrient absorption than when villi are in parallel or randomly organized. The bolus would travel longer in a zigzag flow than in a straight flow, allowing more contact of the nutrients with the absorptive surface of the intestinal epithelium. As for the ileum, all treatment groups presented high density of tongueshaped, making it difficult to analyze them individually.

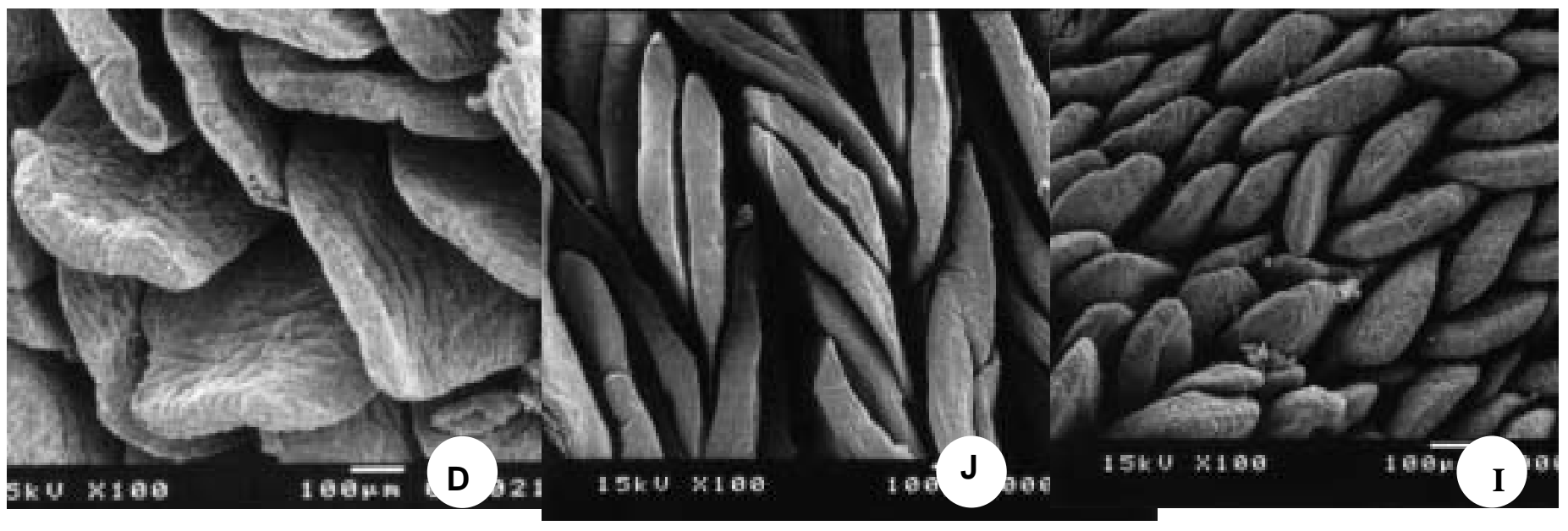

Figurel - Scanning electron microphotograph of intestinal villi in the duodenum (D), jejunum (U), and ileum (I) of 42-day-old broilers 


\section{Pelicano ERL, Souza PA, Souza HBA, Figueiredo DF, Amaral CMC}

\section{CONCLUSION}

The use of growth promoters increased intestinal villi height when Bacillus subtilis was associated to prebiotics. The other tested growth promoters (MOS $+O A, M O S$, and bacterial pool) can be individually used in most circumstances. The tested growth promoters did not influence villi density.

\section{REFERENCES}

Andreatti Filho RL, Sampaio HM. Probióticos e prebióticos. Avicultura Industrial 2000; 1078:16-30.

Balog A, Mendes AA, Takahashi SE, Sanfelice C, Komiyama CM, Almeida Paz ICL, Garcia RG. Efeito do uso de simbiótico e do sistema de criação sobre o desempenho e morfometria do epitélio intestinal de frangos de corte tipo colonial. Anais da Conferência A pinco de Ciência e Tecnologia Avícolas; 2007; Santos, SP. Brasil. Campinas: FACTA; 2007. p.140.

Bradley GL, Savage TF, Timm KI. The effects of supplementing diets with Saccharomyces cerevisiae var. boulardii on male poultry performance and ileal morphology. Poultry Science 1994; 73:17661770.

Cera KR, M ahan DC, Cross RF, Reinhart GA, Whitmoyer RE. Effect of age, weaning and posweaning diet on small intestinal growth and jejunal morphology in young swine. Journal of Animal Science 1988; 66:574-584.

Choi KH, Namkung $\mathrm{H}$, Paik IK. Effects of dietary fructooligosaccharides on suppression of intestinal colonization of Salmonella typhimurium in broiler chickens. Korean Journal of Animal Science 1994; 36:271-84.

Corneli J, Zanella I, Carvalho AD, Raber M R, Pretto AN, Pedroso LC. A valiação das vilosidades intestinais de frangos de corte submetidos a dietas contendo promotores de crescimento alternativos ( $\mathrm{Cd}$ Rom). Anais da $41^{\text {a }}$ Reunião Anual da Sociedade Brasileira de Zootecnia; 2004; Campo Grande, MT. Brasil.

Dionizio MA. Prebióticos como promotores de crescimento para frangos de corte [dissertação]. Lavras (MG): Universidade Federal de Lavras; 2001.

Dobrogosz WJ, Black BL, Casas IA. Delivery of viable Lactobacillus reuteri to the gastrointestinal tract of poultry. Poultry Science 1991; 70:158.

Estat 2.0 Sistema de Análise Estatística. Jaboticabal: Departamento de Ciências Exatas, UNESP; 1992.

Ewing WN, Cole DJA. The living gut: na introduction to microorganisms in nutrition. Dungannon, UK: Context Publication; 1994. 220 p.

Fox SM. Probiotics: intestinal inoculants for production animals. Veterinary Medicine 1988; 83:806-830.
Morphometry and Ultra-structure of the Intestinal Mucosa of Broilers Fed Different Additives

Gomes ER, Demoly P. Epidemiology of hipersensibility drug reactions. Current Opinion in Allergy and Clinical Immunology 2005; $5: 309-316$

lji PA, Tivey DR. Natural and synthetic oligosaccarides in broiler chicken diets. Word's Poultry Science Journal 1998; 54:129-143.

Loddi MM. Probióticos, prebióticos e acidificante orgânico em dietas para frangos de corte [tese]. Jaboticabal (SP): Universidade Estadual Paulista; 2003.

Macari M, Maiorka A. Função gastrintestinal e seu impacto no rendimento avícola. In: Anais da Conferência Apinco de Ciência e Tecnologia Avícolas; 2000; Campinas, SP. Brasil. Campinas: FACTA; 2000; 2:161-174.

Oyofo BA, Deloach JR, Corrier DE, Norman JO, Ziprin RL, Mollenhauer HH. Effect os carbohydrates on Salmonella typhimurium colonization of broilers chickens. Avian Disease 1989a; 33:531-534.

Oyofo BA, Deloach JR, Corrier DE, Norman JO, Ziprin RL, Mollenhauer $\mathrm{HH}$. Prevention of Salmonella typhimurium colonization of broilers with D-mannose. Poultry Science 1989b; 68:1357-1360.

Oyofo BA, Droleskey RE, Norman JO, Mollenhauer HH, Ziprin RL, Corrier DE, Deloach JR. Inhibition by mannose of in vitro colonization of chicken small intestine by Salmonella typhimurium. Poultry Science 1989c; 68:1351-1356.

Pedroso AA. Efeito de probiótico dietético sobre o desempenho, qualidade dos ovos e alguns aspectos morfológicos do trato intestinal e tecido ósseo de galinhas poedeiras [tese]. Jaboticabal (SP): Universidade Estadual Paulista; 1999.

Pelicano ERL, Souza PA, Souza HBA. Prebióticos e Probióticos na nutrição de aves. Ciências Agrárias e da Saúde 2002; 2(1):59-64.

Pelicano ERL, Souza PA, Souza HBA, Oba A, Norkus EA, Kodawara LM , Lima TM A. M orfometria e ultra-estrutura da mucosa intestinal de frangos de corte alimentados com dietas contendo diferentes probióticos. Revista Portuguesa de Ciências Veterinárias 2003; 98 (547):124-134.

Radecki SV, Yokoyama MT. Intestinal bacteria and their influence on swine nutrition. In: Miller ER, Duane EU, Lewis AJ. Swine nutrition. Boston: Butterworth-Heinemann; 1991. p. 439-447.

Radecki SV, Ku PK, Bennink M R, Yokoyama MT, Miller ER. Effect of dietary copper on intestinal mucosa enzyme activity, morphology, and turnover rates in weanling pigs. Journal of Animal Science 1992; 70:1424-1431.

Rostagno HS, Albino LFT, Donzele JL, Gomes PC, Ferreira AS, Oliveira RF, Lopes DC. Tabelas brasileiras para aves e suínos: composição de alimentos e exigências nutricionais. Viçosa: Horacio Rostagno; 2000. 141p.

Santin E, Maiorka A, M acari M, Grecco M, Sanchez JC, Okada TM, M yasaka AM. Performance and intestinal mucosa development of broiler chickens fed diets containing Saccharomyces cerevisiae cell 
wall. Journal Applied Poultry Research 2001; 10:236-244.

Santos EC, Teixeira AS, Freitas RTF, Dias ES, Rodrigues PB, M urgas LDS, Oliveira RFM, Santos EC, Gachett NAB. Uso de promotores de crescimento sobre o desempenho e morfometria intestinal de frangos de corte na fase inicial (Cd-Rom). Anais da $41^{\text {a }}$ Reunião Anual da Sociedade Brasileira de Zootecnia; 2004; Campo Grande, MS. Brasil.

Sato RN. Ação isolada e combinada de probiótico e antibiótico como promotores de crescimento em rações iniciais de frangos de corte [graduação]. Jaboticabal (SP): Universidade Estadual Paulista; 2001.

Savage TF, Cotter PF, Zakrewska El. Effect of feeding a mannanoligosaccharide on immunoglobulin, plasma IgG and bile IgA of Wrolstad M W male turkey. Poultry Science 1996; 75 (Suppl. 1):143.

Schwarz KK, Franco SG, Fedalto LM, Borges AS, Fisher da Silva AV, Pedroso AC. Efeitos de antimicrobianos, probióticos, prebióticos e simbióticos sobre o desempenho e morfologia do jejuno de frangos. Brazilian Journal of Poultry Science 2002; suppl. 4: 75.

Spring P. Effects of mannanoligosaccharide on different cecal parameters and on cecal concentrations of enteric pathogens in poultry [dissertation]. Switzerland: ETH Zurich; 1996.

Spring P, Wenk C, Dawson A, Newman KE. The effects of dietary mannanoligossacharides on cecal parameters and the concentration of enteric bacteria in ceca of salmonella-challenged broiler chicks. Poultry Science 2000; 79: 205-211.

Vicent JG. Antibacterial activity associated with Lactobacillus acidophilus. Journal of Bacteriology 1959; 78:477-484.

Walker WA, Duff LC. Diet and bacterial colonization: Role of probiotics and prebiotics. Journal Nutrition Biochemical 1998; 9: 668-675.

Witte W. Selective pressure by antibiotic use in livestock. International Journal of Antimicrobial Agents 2000; suppl. 1:S19-S24.

Yamauchi KE, Ishiki Y. Scanning electron microscopic observations on the intestinal villi in growing White Leghorn and broiler chickens from 1 to 30 days of age. British Poultry Science 1991; 32:67-78. 